\title{
The Manifestation of Sufism in Wahyu Kolosebo
}

\author{
Wahid Khoirul Ikhwan \\ (khoirulpbsi@gmail.com) \\ UniversitasTrunojoyo Madura, Indonesia
}

\begin{abstract}
Current developments have given birth to millennials. The emergence of the millennial generation or Generation $\mathrm{Y}$ is marked by the increasing use of communication tools, media and digital technology. This will indirectly marginalize Indonesian culture such as the ballad. Therefore, the hymn as part of oral literature needs to be preserved by following the development of the millennial generation because the hymn has a manifestation of religious values that is able to form a more religious, charismatic, and dignified generation of millennials. The purpose of this research is to describe the value of Sufism in the folk song of Wahyu Kolosebo. This study uses descriptive qualitative analysis using content analysis techniques. The results of the study are that the folk song of Wahyu Kolosebo contains Sufis teachings, that is Takhalli is an attempt to rid oneself of despicable traits, such as showing off, prejudiced, inciting, betraying, etc., Takhalli is always behaving obediently with traits that are praised physically and mentally, and Tajalli is a behavior manifesting itself from Allah's grace and guidance.
\end{abstract}

Keywords: Manifestation, Sufism, Folklore, Folk Song

\section{INTRODUCTION}

The Indonesian nation is rich in cultural treasures spread from Sabang to Merauke. Cultural richness can be seen from the diversity of Indonesian people consisting of various tribes, races, and ethnicities. Each tribe, race, and ethnicity has its own cultural characteristics, such as language, art, social form, traditional ceremony, religion, and so on.

Part of Indonesian culture has always been a literary ability. Indonesian people recognize literature starting from the ability to write oral. Hutomo revealed that oral literature is part of the literary form of society as a culture that is passed on orally[1]. Furthermore, Amir explained that oral literature is part of the art of language by using a variety of aesthetic poetic languages. Meanwhile, Taum explains that oral literature is verbal utterances as literary works, such as the use of beautiful temples and to pass on values, legitimacy in socio-politics, as well as solace for listeners[2]

Ethnic groups in Indonesia who have oral-literary abilities are Javanese. Javanese have the ability to make oral literature in the form of songs. According to Ricklefs hymns developed in Javanese society, especially the Javanese Middle East, who told about the legend in the Majapahit era [3]In addition, Zoetmulder mentions that a song is an ancient form of Javanese prose that is sung. Song is sung by special people who have magic[4] According to Chodjim, the function of the hymn when sung with high confidence will cause supernatural powers[5]So that the form of the hymn more nuanced aesthetic that is sacred and mystical. 
In Kamus Besar Bahasa Indonesia, hymns mean songs, songs, poems that are sung[6] Meanwhile, according to Bahtiar hymns are prayers[7] As a prayer, one must believe in the language used, the height of the confrontation, and understand the meaning of the prayer said. Thus, hymns are often used during traditional and religious ceremonies to worship God Almighty. Chanting can make the listener calm if listened to with full of awareness.

According to Ayu, et al. hymns are native songs of East Java that are unique, tickling, witty, containing satire in the form of criticism[8]In addition, hymns are usually used as media to build community conditions that are not in accordance with the customs of the people in East Java. Meanwhile, according to Nurhata, hymns are Old Javanese prose texts in the early period inscriptions[9]Folk song continued to develop in Javanese society before the mayor of Wali Songo. After Wali Songo spread Islam in Javanese society, the existence of the Folk song continued to grow along with the development of Islam. In fact, the song is a medium for the spread of Islam by the Wali Songo. The contents of the hymns are adjusted to the values of the Islamic religion, but their sacred and mystical values still emerge.

One of the hymns that are often sung in Javanese is Folk song Wahyu Kolosebo. Folk song Wahyu Kolosebo was created by Sunan Kalijaga. Folk song Wahyu Kolosebo contains religious values based on Islam. In detail, the Song of Kolosebo Revelation contains a servant's prayer to God so as not to have the nature of anger in the world. Thus, the Song of WahyuKolosebo is very interesting to be examined with the values of Sufism.

Based on Nasution's opinion Sufism is the science of mysticism or Sufism. The broader definition of Sufism is defined as the study of how the relationship between creatures and God is[10]The same thing was also expressed by Hadi W.M. which states that Sufism has an attachment to Sufism from the perspective of the imaging system, the meaning of symbols, and metaphors[11]Sufism has the value of Sufism in the form of expressions of longing between humans and God, the relationship of beings with God, and the character that is religious.

The value of Sufism will be very interesting if it is related to the folk song Wahyu Kolosebo to be investigated. Folk song Wahyu Kolosebo contains the value of relief, which is part of Sufism. Between the folk song Wahyu Kolosebo and the value of Sufism have a connection between them. Thus, researchers are very interested in studying the manifestations of Sufism in the folk song of Wahyu Kolosebo.

\section{RESEARCH METHODS}

This study uses descriptive qualitative methods. According to Moleong qualitative methods are research in which data are in the form of words, images, not numbers[12]Meanwhile, Endraswara explains that one of the characteristics of qualitative research in literary studies is research conducted in the description of meaning in the form of a description in words or pictures, not in the form of numbers[[13]The data of this research are the text of folk song Wahyu Kolosebo. Meanwhile, the data analysis technique uses content analysis techniques. According to Milles and Huberman explained that the content analysis technique is an analysis of continuous, repetitive, and continuous with several stages, namely data reduction, data presentation, and data verification[14]

\section{DISCUSSION}

In concept, Sufism contains the value of truth. The truth value has a narrow scope, which is only a ritual level but also has a meaning of truth that is broad in meaning, namely the meaning of all aspects of life. These aspects of life, according to Nasr are listed in three basic elements 
of Sufism, namely, about goodness, about humanity, and about spirituality[[15]In reality, the Sufism of goodness is a form of the nature of God, whereas human beings are a part of the center of the glory and symbol of God's name and quality. So that Sufism as a media liaison between humans and God through a spiritual journey to get closer to God and the value of truth.

Based on the above understanding, Sufism aims to build direct and conscious engagement with God. So, the Sufis are full of awareness of communicating between spirits and God through reflection and solitude. This agrees with Nurkholis Majid's opinion in Asmaran that Sufism or Sufism teaches worship to God with full awareness so that Sufis like seeing God and being watched by God.[[16]

The Sufis must carry out teachings that are able to direct the relationship to achieve the above activities,. Teachings that can direct the Sufis to reveal the boundary between the Sufis and God, namely through a system of Takhalli, Tahalli, and Tajalli.Takhalli according to Zahri is an attempt to clean oneself from despicable traits, such as showing off, prejudiced, abusing, betraying, and so on[[17]Meanwhile, according to Asmaran Takhalli is an act of cleansing oneself from despicable nature, both physically and mentally[16]. Therefore, humans must distance themselves from the pleasures of the world.

Meanwhile, according to Asmaran Tahalli is always behave obediently with traits praised physically and mentally, so that daily behavior in accordance with the provisions in religion[16]. And Tajalli is a behavior manifesting itself from the grace and guidance of Allah. That is after the Sufis are free from despicable behavior, then their behavior changes with praiseworthy behavior, then the Sufis must appear to Allah's commands.

The discussion of this study will examine the manifestations of Sufism in the folk song of Wahyu Kolosebo. Folk song Wahyu Kolosebo is a form of oral literary work created by Sunan Kalijaga. Contents of the content of the folk song of Wahyu Kolosebo is the teachings of Islam that are makrifat and spiritual charged with the teachings about the authenticity of life. Based on the Javanese dictionary, "Folk song" can be interpreted as poetry, song, mantra. Meanwhile, "revelation" means enlightenment, guidance, and Kolosebo derived from "kolo" and "sebo". "Kolo" means time, period, time, and "sebo" means facing. The definition of Kolosebo Revelation is poetry containing enlightenment or guidance so that humans can face the Almighty.

In the quotation of the folk song Wahyu Kolosebo temple Muslims are encouraged to seek the authenticity of life. The authenticity of life is not easy to be sought by Muslims because it will get temptations from demons or demons. This is in accordance with the poetic quotation below.

\footnotetext{
"Rumeksoingsunlakunistongoyoworo"

"Kelawanmekakhowo, howokangdurangkoro"

"Senajansytetangentayangan, tansahgawerebedo"

"Hinggopupusingjaman"
}

Meaning:

I keep myself from doing what I want

By controlling the air, the air is covered by angkara

Even though the devil roaming around always makes a disturbance

Until the end of time 
Based on the above quotation it is described that humans must struggle to protect themselves from the act of the nature of "nista". The nature of "nista" is a despicable act, such as insulting, despicable act, lying, showing off. In addition, humans must also control the passions, especially passions in the form of "anger" on yourself. "Angkara" is angry at oneself in the form of greed or cruelty. Human who have the nature of anger in his heart wants to have a very versatile, in the need to be respected, really want to be feared, really want to be respected. The nature of lies and the nature of Angkara'swrath "are despicable acts that are always misled by Satan to humans until the end of time.

In the manifestation of Sufism, human behavior that seeks to eliminate and release the insulting nature and anger are included in the teachings of Sufism Takhalli. Disapproving behavior and releasing the insults and fury of anger in an attempt to cleanse sin from liver disease. After the heart is clean from sin, the human soul will be cleaner or purer will be closer to God. So, humans can expose the boundary between humans and God.

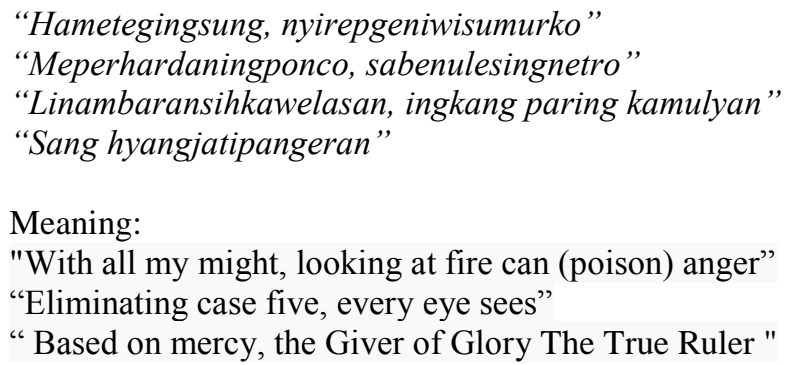

The Folk song text above explains that human efforts to escape from the apostasy made by Satan. Humans must try hard to eliminate the error in the form of anger. With the disappearance of anger in humans, the devil will not be able to master the five things in the human body. Five cases in the human body are the ears, eyes, nose, mouth, and two holes under the stomach (pubic). That is, five things in the human body can cause despicable or sinful qualities. For example, the ear can cause people to behave despicably, such as gossiping, listening to rumors, fighting sheep, slander. The eyes can cause the act of adultery, or see things that are forbidden by religion, while the mouth can cause incitement, lying, pitting, slandering. Efforts to cleanse the human soul are based on the love of the Almighty God.

Based on the verse of the folk song of Wahyu Kolosebo above humans are still trying earnestly to release the despicable human traits. The despicable nature of the stanza is the nature of anger that will cause sin from five things of the human body that will cause sin, such as, ear, eyes, nose, mouth, and two holes under the stomach (pubic). Judging from the manifestations of Sufism, this strophe belongs to the teachings of Sufism Takhalli. When humans are free from reprehensible traits, then humans will be free from liver disease that will not necessarily be stable. Because Satan continues to influence humans to do despicable qualities, therefore humans must understand and absorb the forms of worship in essence, humans must try and get used to suppressing despicable passions with good qualities, avoid doing bad and accustomed to good deeds, and always introspect themselves against the qualities the bad by replacing with good deeds.

\section{"Jianggokalbusamodropepuntoninglaku” \\ "Tumujudatenggustidzat kanga amurbodumadi" "Manunggalingkawulogusti, krentegatibakalmumadi"}




\author{
"Muktiingsungtanpopiranti" \\ Meanings: \\ "Reign in the heart, the ocean guide conducts" \\ "Towards an immaterial God" \\ "Unite it servant with God, a strong desire will be realized" \\ "My happiness without conditions (tools)"
}

Based on the quote from the folk song of Wahyu Kolosebo above, it can be described that if people realize the existence of God's power, then humans will have the power of a clean heart. When humans have clean and pure, they will be united between the servant and his Lord. With the union between the servant and his Lord, all human desires and will be blessed through the prayers he wants. In addition, humans will experience a happy and safe life in this world and the hereafter. This shows that God has power over what He created.

This manifestation of Sufism from human awareness of God's power can be categorized in the teachings of Sufi tahalli. The teachings of Sufism Tahalli always do good and good, according to the guidance of religion. As humans who realize the existence of God, humans have been able to reach a degree of seclusion. Makrifat degree is the degree in which humans are able to witness the existence of God closely. That closeness is usually expressed that God is with humans, like "Manunggaling Kawulo Gusti" (Unite it servant with God). The closeness between man and his God, humans will always be obedient with the truth to God, namely by carrying out all the commandments of God and away from God's prohibitions in earnest.

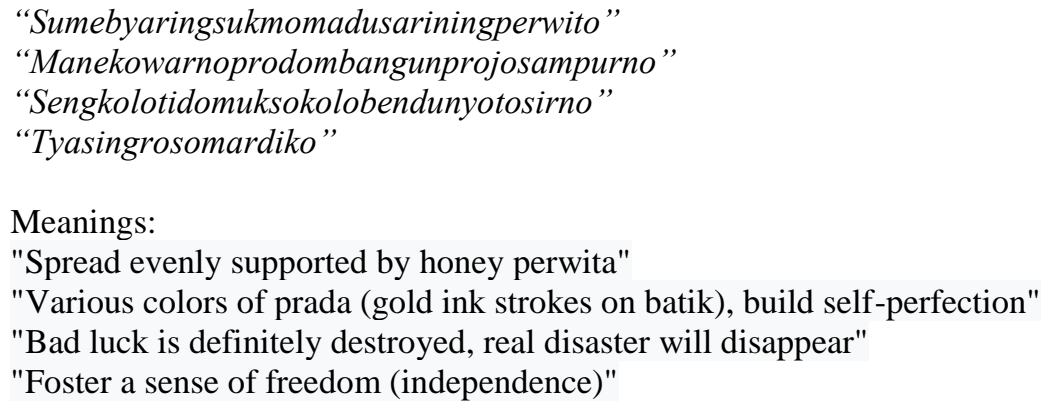

Folk song Wahyu Kolosebo illustrates that humans whose lives are based on religious knowledge and compassion will get the way of the truth of life and get guidance, guidance, and grace from God. In addition, humans will get perfect themselves as humans who are always close to God. When all that is realized, humans will be free from bad luck, sadness, and free from disaster. Thus, humans become free or independent beings from the nature of misleading passion and happiness in the world and the hereafter.

When humans always get guidance and guidance from God means humans have manifested the teachings of sufisne Tajalli. Human Tajalli Sufism always gets the light of God in his heart in the form of grace and guidance from God. Allah's mercy and guidance will make people will get peace, happiness, and coolness in everyday life.

\footnotetext{
"Mugiyo den sedyopusakokalimosodo"

"Yektidadimustikasakjroningjiworogo"

"Bejomulyowaskitodigdoyobowoleksono"

"Byarmanjingsigrosigro"
} 


\begin{abstract}
Meanings:
"Hopefully because of the heirloom sayings of shahada"

"Really become a mustika in the soul"

"Luck, glory, clairvoyance, supernatural powers, and authority"

"Just come in or just materialize"
\end{abstract}

The verse of folk song Wahyu Kolosebo above describes the form of prayer for the creator of the hymn to give true faith in the form of two sentences of Shahada. In addition, the creator of the hymn hopes to be given luck and the glory of life, has extensive knowledge and knowledge, has the courage to defend the truth, and is authoritative. So, it can be an example for others and beneficial for those around him to be able to feel the perfect life in accordance with the love of Allah the Most Great.

Prayer is a human endeavor that wants to draw close to God. By praying, humans hope to get light from God, so that people get the authenticity of life. Prayer always reflects requests for good or good qualities. In manifestation, Sufism includes the teachings of Sufi tahalli. The creator of the ballad tries to find good qualities in his prayer. Manifestations of the teachings of Sufism thalli are also found in the folk song Wahyu Kolosebo temple below.

"Ampuhsepuhwutuh tan keno isopaneluh"

"Gagahbungahsumringahndadaringwayah-wayah"

"Satriototosembodowirotomokatonsewukartiko"

"KetamanwahyuKolosebo"

Meanings:

"Effective, elderly, intact, cannot be mastered (magic)"

"Dashing cheerfully, fretting every time"

"Staria layout, wiratama looks a thousand stars"

"Infused with instructions when facing Him"

This stanza is a continuation of the prayer of the creator of the folk song of Wahyu Kolosebo. In this prayer, the creator of the folk song of Wahyu Kolosebo realized in his prayer that someone close to God, united with God would have perfect strength, such as the power that would protect against the power of evil magic. In addition, the person will act wisely and nobly, and his face emits light that will reduce all elements of anger and hatred. In fact, someone will be a hero who spreads peace that will bring prosperity in accordance with God's direction. Human effort above as an attempt to carry out the traits of praise in this life.

A description of the effort to perform good qualities is also implied in the next stanza. Thus, the next stanza contains manifestations of the teachings of Sufi tahalli. The following is the verse of the folk song of Wahyu Kolosebo that describes the teachings of Sufi tahalli.

\title{
"Memujiingsungkantisuwitolinuhung" \\ "Segorogondoarumswuh re dupokemelun" \\ "Ginulahniatingsunghangdungsabdokangluhur" \\ "Titahing sang hyangagung"
}

Meanings:

"I praise by facing the Most High" 
"The ocean smells nice, like incense smoke is raging"

"Due to my intention, chanting noble words"

"The Supreme Being"

Furthermore, the prayers of the creator of the folk song Wahyu Kolosebo that pray as humans hope to be given victory and resurrection in the world by God. What is meant by victory and resurrection is victory and resurrection in the fight against the nature of the passions and despicable qualities. So that by becoming a clean and pure human from heart disease, people will struggle throughout the world to spread and uphold these good qualities to other humans in the world.

The prayer effort is also still truly manifested by the affection between the servant and God. The form of affection is a form of the heart of a holy water. This still illustrates the effort to perform good qualities also implied in the next stanza. Thus, the next stanza contains manifestations of the teachings of Sufi tahalli. The following is the verse of the folk song of Wahyu Kolosebo that describes the teachings of Sufi tahalli.

"Rembesingtresnotondoluhingnetroroso"
"Rosorasaningatikadyotirtokangsuci"
"Kamistorojopomontrokondangdadipepadang"
"Palilahing sang hyangwenang"”

Meanings:

"Seepage of affection, a sign of taste water"

"Feelings of heart, like holy water"

"Embodied in the recitation of a mantra (prayer), (known to people) famous for being a light"

"By the power of the Almighty"

In the folk song of the Wahyu Kolosebo above can be described that love or love will give birth to tears. Tears will form the soul and heart that is completely in the human self. Thus, humans will understand the nature of love is sacred, as holy as the tears that wet the earth. Therefore, people hope that through prayer they will meet God in the sanctity of tears. And God is in control of the souls of people who have a pure love.

\title{
"Nowodewojawototalisantikobawono" \\ "Prasidosidokoroingsasonoasmoroloyo" \\ "Sri narendroKolosebowinisudoinggegono" \\ "Datangingsirsewusewuwarso"
}

\author{
Meanings: \\ "The nine forms of deity, the universal power cord" \\ "Badi praises in heaven" \\ "The king of the Kolosebo, graduated in the sky" \\ "Will not sink a thousand years"
}

Based on the quote of the folk song of Wahyu Kolosebo above can be described that there is no magic rope that is able to bind nine dimensions on earth. Which can bind the nine dimensions on earth only the warriors who have a modest nature, virtuous, character who began, like to 
share goodness and not afraid to fight to defend the truth of God's teachings. When there is a warrior like that, then the warrior is entitled to the crowning gift of the king as a disseminator of peace and prosperity in the world, namely the paradise of God. In fact, angels will marvel as special creatures of God. In fact, if you can live with these knights like a happy life that has not been said for a thousand years.

In the last stanza folk song Wahyu Kolosebo describes the teachings of Tajalli Sufism. humans who reach the dimension of Tajalli will get the light of the spirit of Allah. Tajalli dimension is a media to purify and cleanse the self-deprecated traits and familiarize yourself with the form of commendable qualities. If humans are clean from sin, then they will feel close to God. But on the contrary, if humans sin a lot, then humans will stay away from God. The view of Sufis ridding themselves of these despicable qualities is very important because despicable traits are filth which will keep away from God.

\section{CONCLUSION}

Folk song Wahyu Kolosebo is part of oral literature which contains the values of Sufism teachings, namely Takhalli, tahalli, and Tajalli. The values of Sufism teachings are very important in the implementation of today's life because Sufism teachings can answer the challenges of modern times, such as alienation and dryness of spiritual values. Furthermore, the value of the teachings of Sufism is able to provide solutions for modern society, especially generation $\mathrm{Y}$ or millennial generation from moral crises, spiritual crises, and crises of belief. If related to social life now, the value of Sufism teaches enlightenment for the community, such as giving examples of commendable qualities in society.

\section{REFERENCES}

[1] S. S. Hutomo, "Mutiara yang Terlupakan: Pengantar Studi Sastra Lisan.," no. Surabaya: Himpunan Sarjana Kesusasteraan Indonesia., 1991.

[2] T. Y.Y., "Studi Sastra Lisan: Sejarah, Teori, Metode, Dan Pendekatan Disertai Contoh Penerapannya.," no. Lamalera, 2011.

[3] M. C. Ricklefs, A History of Modern Indonesian since 1200, 3rd ed. Basingstoke, 2001.

[4] P. J. Zoetmulder, Kalangwan: Sastra Jawa Kuna Selayang Pandang. Jakarta: Djambatan, 1983.

[5] A. Chodjim, Mistik dan Makrifat Sunan Kalijaga. Jakarta: Serambi, 2007.

[6] Depdikbud, Kamus Besar Bahasa Indonesia. Jakarta: Balai Pustaka, 1995.

[7] H. Z. Bahtiar, "Folk song : Myth of Welfare for Kutuhuk People in Kudus Regency," Harmon. J. Art Res. Educ., vol. 14, no. 2.

[8] Ayu, "Kajian Interaksionisme Simbolik Folk song Jula Juli Pada Pementasan Ludruk Irama Budaya," Fonema, vol. 4, no. 2, 2017.

[9] Nurhata, "Naskah Folk song Nabi :Analisis Tema dan Fungsi Sosial," MetasastraJurnal Penelit. Sastra, vol. Vol. 10, N, 2017.

[10] H. Nasution, Falsafah dan Mistisis Medalam Islam. Jakarta: Bulan Bintang, 1973.

[11] A. Hadi, W. M., Kembali ke Akar Kembali ke Sumber: Esai-Esai Sastra Profetik dan Sufistik. Jakarta: Pustaka Firdaus., 1999.

[12] L. J. Moleong, Metodologi Penelitian Kualitatif. Bandung: PT Remaja Rosdakarya Offset, 2007.

[13] S. Endraswara, Metodologi Penelitian Sastra, 1st ed. Jakarta: Caps, 2011.

[14] B. M. M. H. Miles, Analisis Data Kualitatif Buku Sumber Tentang Metode-metode Baru. 
Jakarta: UIP, 1992.

[15] S. H. Nasr, Sufi Essays. Albany: State University of New York Press: State University of New York Press, 1991.

[16] Asmaran A.S, Pengantar Studi Tasawuf. Jakarta: Raja Grafindo Persada, 1996.

[17] M. Zahri, Kunci Memahami Tasawuf. Surabaya: Bina lmu, 1995. 